\title{
Hobbes and Samuel: reply
}

\author{
Arye L. Hillman
}

Received: 25 March 2009 / Accepted: 22 April 2009 / Published online: 7 May 2009

(C) Springer Science+Business Media, LLC 2009

\begin{abstract}
Geoffrey Brennan has presented a defense of Hobbes against the claim of misrepresentation of the prophet Samuel as supporting a leviathan. He has also used the occasion of his reply to introduce embellishments that were outside of the scope of my observations concerning the prophet Samuel and Hobbes.
\end{abstract}

Keywords Prophet Samuel $\cdot$ Hobbs $\cdot$ Leviathan

JEL Classification B11 $\cdot$ B32

\section{Brennan's defense of Hobbes}

Geoffrey Brennan has taken upon himself to defend Hobbes against the charge that Hobbes misrepresented the prophet Samuel to be a supporter of the leviathan. Whether Hobbes quoted Samuel normatively to indicate the rights that a king should have (as I propose, Hillman 2009) or quoted Samuel in a positive context as a prediction of how a king will behave (as Brennan suggests), the fact is that Hobbes favored a leviathan and Samuel did not. Had Hobbes informed readers of Samuel's warning against choosing a king, we might indeed conclude, as Brennan would have us do, that Hobbes was pointing to limitations on personal freedom of having a leviathan who was nonetheless necessary because of the need to restrain the evil in human nature. Because of Hobbes' omission of Samuel's warning, Brennan's defense of Hobbes has had to rely on interpretation and imputation. With Hobbes making a case for a leviathan and Samuel warning against a leviathan, the burden of proof in a defense of Hobbes is a credible explanation for why Hobbes chose to stop short of telling his readers that Samuel opposed a leviathan. The point of my paper is that Hobbes should have looked, not to Samuel, but elsewhere for precedent in support for his leviathan. Readers can judge if Geoffrey Brennan has convinced them otherwise (Brennan 2009).

I thank Heinrich Ursprung and Warren Young for helpful comments and Joel Guttman, Daniel Levy, and Hillel Rapoport for discussions.

A.L. Hillman $(\bowtie)$

Department of Economics, Bar-Ilan University, Ramat Gan 52900, Israel

e-mail: hillman@mail.biu.ac.il 


\section{The continuation of Samuel's warning}

Brennan puzzles over why, when pointing out Samuel's warning against choosing a king, I did not include Samuel's further statement that the people should not expect to be saved from the king by divine intervention. Samuel had already told the people that they would regret choosing a king and he added that cries for divine help would remain unanswered-if otherwise, of course, there would be no cause for regret.

\section{Divine or human intervention?}

I chose to keep issues to the level of man and man whereas Brennan is much concerned with divine presence and interlocution, and divine help. ${ }^{1}$ People subject to a leviathan may well plead for divine help; still, we can surmise that people who cry out to be saved from the tyranny of a leviathan would settle for human rather than divine intervention. Although Brennan leads us in the direction of a role for the divine, my preference remains to set aside issues regarding the divine as unnecessary for a consideration of how Hobbes misused the words of the prophet Samuel. ${ }^{2}$

\section{Samuel's motives}

In another embellishment, Brennan proposes that Samuel was moved by self-interest to resist a king because the king would compromise Samuel's authority. Samuel's concerns about the adverse consequences of choosing a king appear to have been of a longer-term perspective than his own remaining lifetime.

\section{Restraint on the rule of the king}

Brennan returns to the point that I noted that the people wanted a king as had other nations; as I indicated, the rulers of Israel were not intended to be kings in the manner of the kings of other nations because a king or queen of Israel could not make laws but rather could only rule subject to principles of the rule of law that had been enunciated. The distinction is not subtle between wanting a king who would abide by the protections afforded by the pre-enunciated principles of the rule of law and wanting an absolute ruler of the sort that the other nations had, and indeed would continue to have through the coming millenniakings and also queens and other rulers who often used their authority in wanton and cruel ways. ${ }^{3}$ Samuel was referring to the type of king unrestrained by prior designated principles of property rights and justice, and hence opposed a king (or leviathan).

\footnotetext{
${ }^{1}$ Brennan's emphasis on unanswered cries for divine help alludes to the doctrine of deserved collective punishment. The doctrine was promulgated in reference to other debates initiated some centuries after the time of Samuel.

${ }^{2}$ I thank, however, Geoffrey Brennan for a discussion on the role of the divine.

${ }^{3}$ On Nietzschean rulers and failure of economic development in contemporary times, see Hillman (2004). 


\section{When is deception justified?}

Was Hobbes' deception in omitting Samuel's warning against a leviathan justified in serving a higher cause? The higher cause would be that the leviathan would beneficially save people from their own evil and base nature. Yet Samuel did not regard a leviathan as at beneficial and we trust authors to act responsibly in representing others' writings and not to misrepresent or impute that which was not intended. My purpose was to defend Samuel against misrepresentation. Deception is obligatory when a life can be saved, when people can be spared injury or even embarrassment, or in general to preempt evil intent. These circumstances did not apply to Hobbes' misrepresentation of Samuel. We would, for example, come to the defense of Locke or Hayek if they were to be misrepresented as supporting leviathan government. Samuel merits the same defense.

\section{The persistence of deception}

How could Hobbes' misrepresentation by omission of Samuel's warning have continued for as long as it did after the publication of Leviathan? The possibilities are that Hobbes' deception went unnoticed or that those seeking to point out the deception were silenced. ${ }^{4}$

\section{References}

Aschheim, J., \& Tavlas, G. S. (2004). Academic exclusion: the case of Alexander Del Mar. European Journal of Political Economy, 20, 31-60.

Brennan, G. (2009, in press). Hobbes' Samuel. Public Choice.

Hillman, A. L. (1998). Political economy and political correctness. Public Choice, 96, 219-239. Reprinted in: Congleton, R. D., Hillman, A. L., \& Konrad, K. A. (Eds.) (2008). Forty years of research on rent seeking 2-Applications: rent seeking in practice (pp. 791-811). Berlin: Springer.

Hillman, A. L. (2004). Nietzschean development failures. Public Choice, 119, 263-280.

Hillman, A. L. (2009). Hobbes and the prophet Samuel on leviathan government. Public Choice. doi:10.1007/s11127-009-9447-6.

\footnotetext{
${ }^{4}$ For an interesting case study of academic silencing, see Aschheim and Tavlas (2004). On political correctness, which also inhibits criticism, see Hillman (1998).
} 